\title{
Teacher's Performance in Public Senior High School (A study in Bungo City, Jambi Province, Indonesia)
}

\author{
Ermita $^{1}$ and Hade Afriansyah ${ }^{2}$
}

\author{
${ }^{1}$ Universitas Negeri Padang, Padang, Indonesia, $ه$ (email),ermita@fip.unp.ac.id \\ ${ }^{2}$ Universitas Negeri Padang, Padang, Indonesia, $ه$ (email), hadeafriansyah@fip.unp.ac.id
}

\begin{abstract}
Teaching involves the arts of teachers to manage all of their teacher preparation, implementation, and evaluation. This article aims to describe how high teacher's performance in public senior high school and how to increase it. There are 54 teachers as the sample in this research chosen by proportional stratified random sampling. Researchers used questionnaire with Likert scale to collect data in this research, after conducting its validity and reliability test. Then data were analyzed by using correlation and regression techniques. The results show that teachers in public senior high school are categorized good performance. Based on the theory, researchers gave some suggestions to teacher to increase their performance. The teachers are suggested to join some events such as conference, motivation seminar, workshop, etc. to upgrade their ability and professionalism. Therefore, the teachers can plan their learning activity well, carry out learning activity well, assess learning outcomes with complete aspects, guide and train students, and carry out additional assignments properly.
\end{abstract}

Keywords: Teacher's Performance, professional teacher, evaluation, preparation,

\section{INTRODUCTION}

The educational purpose is to change students in order to be better than before. It is in line with Smagorinsky (2015) about language art states that what student growth is related to human development. There are a lot of scopes of educational discussion that have discussed. All of them only aim at changing students for the better life. So changes in students for the better human can be used as indicators to measure how successful the education has been. Discussion about the curriculum, infrastructure, educators and education personnel, financial support, school and community relations, special services, and administration are important, but must be linked to the success of changing students for the better as the indicator. If not, then the discussion will be in vain

The teacher plays an important role in educating students in a better direction. Among all aspects discussed above the greatest contribution to the change of students for the better is the role of the teacher. Educators or teacher standards in Indonesia are regulated in Minister of Education Regulation Number 16 of 2007 concerning Academic Qualification Standards and Teacher Competencies. The large role of teachers in achieving educational goals encourages researchers to conduct research on the performance of teachers in Bungo District, Jambi Province, Indonesia.

Previous researchers have reported some aspects of teachers' performance, such as, scaffolding by English language teachers (Hamzah \& Rozimela, 2018), pedagogical competence of Indonesian language teachers
(Kumalasari, Setiawan, \& Sumarlam, 2017), media in listening (Asmar \& Ardi, 2013). However, their research only focusses on the learning activity. Meanwhile this research evaluates all teachers' performance indicators.

Currently, teachers' performance are assessed and categorized as certified teachers. In Indonesia, professional teachers are given certificate after evaluating their performance. Similarly, National Board English Language Arts Certification evaluate English teacher in US. (Delandshere \& Petrosky, 2001). Therefore, there is a need to assess teachers' performance to evaluate their profesionalism at work.

\section{THEORY}

The Definition of performance

In organizational life the term performance is often used in any conversations. According to Wibowo (2011: 261) performance can be seen as a process or work result based on certain predetermined targets. There are some opinions that interpret performance as the result of work alone. According to Usman (2011: 486) performance is the work process carried out by a person in his field of work. Bangun (2012: 231) also argues that performance is a work process carried out by a person based on job standards. The same thing was stated by Mukhtar (2009: 128) that performance is a work process that is concrete, observable, and measurable. Rifai and Sagala (2009: 604) stated that a person is said to have a good performance if he has done a task as well as possible. 
Based on some of the opinions above, one opinion states that performance is a process and work, and three opinions state that performance is a process, and one opinion states that performance is an outcome. Many opinions state that performance is a process, so it can be concluded that performance is a process carried out by someone in carrying out the tasks assigned to him.

\section{The Assessment of Performance}

In an organization, performance appraisal is often done, so understanding related job appraisal is important to know. Sunarto (2007: 197) argues that performance appraisal is actually an assessment of human behavior in carrying out the roles they play in the organization. According to Bangun (2012: 231) performance appraisals is a process carried out by the organization to evaluate or assess the success of employees in carrying out their duties.

Based on the two opinions above that emphasize that performance appraisal is an assessment conducted on someone in carrying out their duties. If it is related to the performance of a teacher, it is important to know the teacher's tasks. Prawiradilaga (2007: 3) explains that there are four tasks of a teacher, namely: (1) planning teaching and learning programs, (2) implementing the teaching and learning process, (3) evaluating student learning outcomes, and (4) preparing learning materials.

In the Guidelines for the Implementation of the Task for Teachers and Supervisors of the Direktorat Jenderal Peningkatan Mutu Pendidik dan Tenaga Kependidikan Departemen Pendidikan Nasional in 2009 states that the workload as the principal activities of teachers as stated in Government Regulation Number 74 Year 2008 about teachers article 52 namely (1) planning learning, (2) implementing learning, (3) assessing learning outcomes, (4) guiding and training students, (5) carrying out additional tasks.

Peraturan Menteri Negara Pendayagunaan Aparatur Negara dan Reformasi Birokrasi No. 16 Tahun 2009 Chapter II article (5) paragraph (1) states that the main task of teachers is to educate, teach, guide, direct, train, assess, and evaluate students in early childhood education. formal education pathways, basic education and secondary education as well as additional tasks relevant to the function of schools / madrasas.

From the opinion of Prawiradilaga above, in point four we can input it into point one, because preparing lesson material is one part of planning teaching and learning programs. So that we can summarize these opinions into three points, namely (1) planning teaching and learning programs, (2) implementing the teaching and learning process, (3) assessing student learning outcomes, these three points are supported by the Pedoman Pelaksanaan Tugas Guru dan Pengawas Direktorat Jenderal Peningkatan Mutu Pendidik dan Tenaga Kependidikan Departemen Pendidikan Nasional Tahun in 2009, the Guidelines also state that the duties of other teachers are to guide and train students, and carry out additional tasks. The statement above says teacher assignments are also contained in the Peraturan Menteri
Negara Pendayagunaan Aparatur Negara Dan Reformasi Birokrasi Nomor 16 Tahun 2009 BAB II article (5) paragraph (1) previously discussed.

Thus, it can be concluded that the teacher's tasks are (1) learning planning, (2) learning implementing, (3) evaluation of learning outcomes, (4) student's mentoring and training, (5) additional duty.

The Benefits of Teacher Performance Assessment

Performance appraisal of individuals is very beneficial for an organization. With the assessment will be known the actual conditions about performance. Bangun (2012: 232) argues that one of the benefits of performance appraisal is to provide a basis for identifying training needs and personnel development. According to Alwi (2001: 187) theoretically the benefits of assessment are categorized as an evaluation and development. Evaluation must refer to: (1) assessment results are used as a basis for compensation, (2) assessment results are used as staffing decisions, (3) assessment results are used as a basis for evaluating the selection system. Whereas development assessment must refer to: (1) real achievements of individuals, (2) individual weaknesses that impede performance, and (3) achievements that are developed. Siagian (2003: 158) stated the results of an objective and rational performance evaluation would be useful for:

1. Enables all employees to be able to further improve performance.

2. Help companies to be able to take into account the provision of rewards.

3. Assist leaders in considering giving promotions and assignments.

4. Provide consideration in determining the importance of training.

5. Helping employees to plan career development in the future.

6. Helping personnel to improve employee recruitment procedures.

7. Assist leaders in perfecting HR information systems.

8. Improving the system design of work because of low performance may be due to an incorrect design system.

9. Helping companies to improve their ability to face future challenges.

From the three opinions above, it can be concluded that the performance appraisal is very much beneficial for the organization. Teacher performance appraisal is really needed for schools, so that the benefits as described above can be realized. In this study, the results of teacher performance appraisal are used to see how much the contribution of work motivation and cooperation climate affect teacher performance.

\section{The Factors Affecting Performance}

Marwansyah (2010: 234) states that performance problems in organizations can be caused or caused by many factors. These factors can be grouped into four main causes of the following performance problems: (1) knowledge or skills, (2) environment, (3) resources, (4) motivation. Almost in line with this opinion Griffin (2000: 
98) argues that the best performance is determined by three factors, namely: (1) motivation, (2) ability, (3) work environments. In line with that Usman (2011: 250) states that performance depends on motivation, ability and environment. Wibowo (2007: 67) states that there are several factors that need to be considered for an organization that has good performance, some of which are human resource management and the climate of cooperation.

Simanjuntak (2005: 19) states that performance improvement can be done among others by (1) encouraging workers to understand job descriptions, (2) encouraging workers to understand the goals to be achieved, (3) helping workers understand how to do work, (4) empowering workers through guidance, counseling, and others, (5) fostering motivation and work ethics, and (6) creating a conducive climate of cooperation.

Based on the five opinions above related to factors that affect teacher performance, it is known that several factors are the same from one opinion to the other, namely: ability, environment, climate of cooperation, and motivation. From Marwansyah's opinion related to the knowledge or skill factor we can combine it into the ability factor in other opinions, and we can eliminate the resource factor because it is too broad. Thus, it can be concluded that teacher performance can be influenced by several factors including: (1) ability, (2) environment, (3) motivation, (4) management, and (5) climate of cooperation.

From the overall discussion regarding the above performance, it can be concluded that the teacher's performance in this study is the result of work done by the teacher in carrying out the tasks assigned to him. The teacher performance indicators are as follows: (1) learning planning, (2) implementation of learning, (3) assessment of learning outcomes, (4) mentoring and training of students, (5) additional duty.

\section{METHOD}

This research method is a descriptive research method, which explains in detail about how high the performance of teachers in schools in Bungo District, Jambi Province, Indonesia. Researchers collected data from 54 teachers as samples by using a Likert scale questionnaire that had been validated and discussed with experts first.

\section{Instrument Development}

Research data from teamwork climate variables were collected using a Likert scale model questionnaire instrument. This scale was developed by Rensis Likert with always (SL), often (SR), sometimes (KD), rare (JR) and never (TP) categories. The instruments are arranged by steps (1) making a grid based on variable indicators, (2) compiling question items, and (3) conducting rational analysis.

\section{Instrument Testing}

The number of respondents testing questionnaires in populations that have similar criteria with sample are 30 people. Analysis of the results of the trial data was conducted to determine the level of validity (reliability) and reliability (reliability) of the instrument by using SPSS 16 help. The formula used to test validity is Product Moment. Whereas to test the reliability used Cronbach Alpha formula. The results of the validity test of teacher's performance using SPSS can be seen that the items that fall are 9, 18, 24, 26, dan 29 of the items as many as 33 items so that the remaining items are 28 items.

Table 1. Summary of instrument item analysis (validity) results

\begin{tabular}{|c|c|c|c|c|}
\hline $\begin{array}{c}\text { Variab } \\
\text { le }\end{array}$ & Indicator & $\begin{array}{c}\text { Number } \\
\text { of Valid } \\
\text { Items }\end{array}$ & $\begin{array}{c}\text { Number } \\
\text { of Valid } \\
\text { Items }\end{array}$ & $\begin{array}{c}\text { Number } \\
\text { of Valid } \\
\text { Items }\end{array}$ \\
\hline \multirow{8}{*}{$\begin{array}{l}\text { Teacher } \\
\text { Perform } \\
\text { ance }\end{array}$} & -Learning & 8 & - & 8 \\
\hline & planning & 11 & 2 & 9 \\
\hline & $\begin{array}{l}\text { - Learning } \\
\text { implementa } \\
\text { tion }\end{array}$ & 6 & 1 & 5 \\
\hline & $\begin{array}{l}\text { i-Evaluation } \\
\text { of }\end{array}$ & 5 & 2 & 3 \\
\hline & $\begin{array}{l}\text { learning } \\
\text { outcomes }\end{array}$ & 3 & - & 3 \\
\hline & $\begin{array}{l}\text {-Student's } \\
\text { mentoring } \\
\text { and } \\
\text { training }\end{array}$ & & & \\
\hline & $\begin{array}{l}\text { - Additional } \\
\text { duty }\end{array}$ & & & \\
\hline & Total & 33 & 5 & 28 \\
\hline
\end{tabular}

The results of the instrument reliability analysis are known as the table below.

Table 2. summary of instrument reliability analysis results

\begin{tabular}{|l|c|c|c|}
\hline \multicolumn{1}{|c|}{ Variabel } & rtt & $\begin{array}{c}\mathbf{r} \text { tabel } \\
(\boldsymbol{\alpha}=\mathbf{0 , 0 5}, \\
\mathbf{D F}=\mathbf{2 8})\end{array}$ & Remark \\
\hline $\begin{array}{l}\text { Teacher } \\
\text { Performance }\end{array}$ & 0,972 & 0,374 & Reliable / good \\
\hline
\end{tabular}

Based on the results of the instrument reliability analysis above it can be concluded that the teacher's performance instrument can be used as a research data collection tool because of the price of $\mathrm{rtt}>\mathrm{r}$ table (at the level of $\alpha=0.05$ and $\mathrm{DF}=28$ ).

\section{RESULT AND DISCUSSION}

\section{Descriptive Analysis}

The description of this data presents the state of the research variables, including the mean score, median, mode, standard deviation, frequency distribution table, frequency distribution histogram image, data frequency distribution histogram image, and respondent achievement 
level of each research variable using ideal score analysis using the formula:

$$
\text { Ideal_Score }=\frac{\text { Mean_Score }}{\text { Mak.s_Score }} x 100 \%
$$

By categorizing the level of achievement of respondents used according to Sudjana classification [15] as follows:

$$
\begin{array}{ll}
90 \%-100 \% & \text { Very Good } \\
80 \%-89 \% & \text { Good } \\
65 \%-79 \% & \text { Enough } \\
55 \%-64 \% & \text { Poor } \\
0 \%-54 \% & \text { Not Good }
\end{array}
$$

From the description analysis, it can be seen that the average value (mean), median and mode do not exceed the standard deviation. According to Irianto (1988: 58) if the difference in the average value, median and mode does not exceed one standard deviation then the data tends to be normal. So it can be stated that the Teacher Performance variable is normally distributed. An illustration of the frequency distribution of teacher performance scores can be seen in Figure 1.

\section{Table 3. Description of teacher's performance data}

\begin{tabular}{cc}
\hline Description & Teacher Performance \\
\hline Mean & 119.46 \\
\hline Median & 119.00 \\
\hline Mode & $116.00^{\mathrm{a}}$ \\
\hline Std. Deviation & 7.32 \\
\hline Minimum & 103.00 \\
\hline Maximum & 136.00 \\
\hline
\end{tabular}

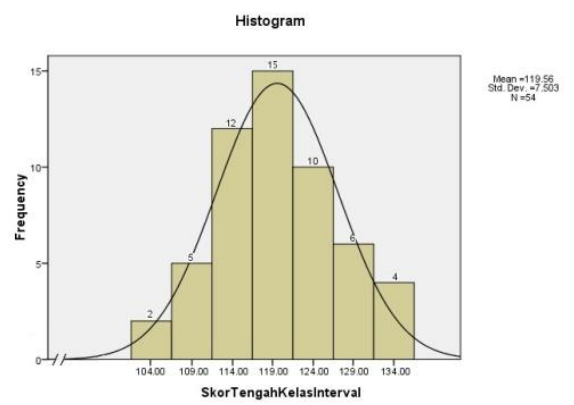

Fig. 1. Normality Histogram of Teacher's Performance Data

Table 4 below appears that the highest indicator achievement level is the Learning Planning indicator of $86.80 \%$ with a good category and the lowest achievement level is the Learning Outcomes Assessment indicator of $83.64 \%$ with a good category.

In general, the level of achievement score was $85.33 \%$ in the good category. This means that the performance of teachers at the Middle Rimbo Tengah District of Bungo District is seen from the aspects of

\begin{tabular}{|c|c|c|c|c|}
\hline No Indicator & $\begin{array}{l}\text { Ideal } \\
\text { Score }\end{array}$ & $\begin{array}{l}\text { Mean } \\
\text { Score }\end{array}$ & $\begin{array}{l}\text { Performance } \\
\text { Level }(\%)\end{array}$ & Remark \\
\hline $\begin{array}{l}1 \text { Learning } \\
\text { planning }\end{array}$ & 40 & 34,74 & 86,80 & Good \\
\hline $\begin{array}{ll}2 & \text { Learning } \\
\text { implementation }\end{array}$ & 45 & 38,20 & 84,89 & Good \\
\hline $\begin{array}{l}3 \text { Evaluation of } \\
\text { learning } \\
\text { outcomes }\end{array}$ & 25 & 20,91 & 83,64 & Good \\
\hline $\begin{array}{l}4 \text { Students' } \\
\text { mentoring and } \\
\text { training, }\end{array}$ & 15 & 12,70 & 84,67 & Good \\
\hline 5 Additional duty & 15 & 12,93 & 86,20 & Good \\
\hline
\end{tabular}

planning learning, implementing learning, evaluating learning outcomes, mentoring and training students, and implementing additional tasks well.

Table 4. Summary of instrument item analysis (validity) results

\section{Discussion}

Based on this research finding, it indicates that the teachers' performance are categorized as good. This finding enrich the information of the previous researchers about teachers' performance. Hamzah \& Rozimela (2018) who investigate scaffolding used by English teachers at senior high school in West Sumatra. Their research only focus on the learning activity. Meanwhile this research evaluate all teachers' performance indicators. Similarly, Kumalasari, et al. (2017) focus her research only on pedagogical competence. However, the present study involves preparation until assessment conducted by the teachers.

To increase their performance, teacher can join some enlightment events to upgrade their professionalism, such as conference, motivation seminar, workshop, etc. In order teacher can plan learning well, carry out learning well, assess learning outcomes with complete aspects, guide and train students, and carry out additional assignments properly. It can be guided by some evaluation standard defined by the government board (Smagorinsky, 2015).

\section{CONCLUSION}

Based on the research result, it can be concluded that teacher performance in public senior high school in Bungo City, Jambi Province, Indonesia, is in good category. It is 85.33. Then base on the theory, researchers give some suggestions to teacher to increase their performance. teacher is suggested to join some events to upgrade their ability such as conference, motivation seminar, workshop, etc. In order teacher can plan learning well, carry out learning well, assess learning outcomes with complete aspects, guide and train students, and carry out additional assignments properly. 


\section{REFERENCES}

[1] Asmar, Y. \& Ardi, H. (2013), "Listening media" application in preparing listening material. Lingua Didaktika: Jurnal Bahasa dan Pembelajaran Bahasa, 6(2), 120-135.

[2] Bangun, W. (2012). Manajemen Sumber Daya Manusia. Jakarta: Erlangga.

[3] Delandshere, G., Petrosky, A.R. (2001). Framing Teaching and Teachers? National Board English Language Arts Certification in the US. L1Educational Studies in Language and Literature 1, 115-133. https://doi.org/10.1023/A:10127640 31641

[4] Hamzah. \& Rozimela, Y. (2018) The use of scaffolding by English teachers at senior high school in West Sumatera. Lingua Didaktika: Jurnal Bahasa dan Pembelajaran Bahasa. 12(1), 25-33.

[5] Kumalasari, S.P. Setiawan, B. \& Sumarlam. (2017). Pedagogical competence of indonesia teacher viewed from the anecdote writing lesson planning. Lingua Didaktika: Jurnal Bahasa dan Pembelajaran Bahasa, 11(2), 146-156.

[6] Marwansyah. (2010). Manajemen Sumber Daya Manusia. Alfabeta: Jakarta

[7] Mukhtar, A. M. (2009). Audit Sistem Informasi. Jakarta: Rineka Cipta

[8] Prawiradilaga, Salma, Dewi. (2007). Prinsip Disain Pembelajaran. Jakarta: Kencana

[9] Siagian, P, S. (2003). Teori Motivasi dan Aplikasinya. Rineka Cipta: Jakarta

[10] Simanjuntak, J., P. (2005). Manajemen dan Evaluasi Kinerja. Jakarta: Lembaga Penerbit Fakultas Ekonomi Universitas Indonesia

[11] Smagorinsky, P. (2015). Growth through language arts and the conundrum of teacher evaluation. Language Arts, 93(2), 108-119.

[12] Usman, H. (2011). Manajemen: Teori, Praktek, dan Riset Pendidikan. Jakarta: Bumi Aksara

[13] Wibowo. (2007). Manajemen Kinerja. Jakarta: Raja Grafindo Persada

[14] Wibowo. (2011). Manajemen Kinerja. Jakarta: Rajawali Pers 